\title{
Factors Analysis on the Level of Cash Dividend in Chinese Gem Listed Companies
}

\author{
Lin Huijuan, Huang Qianhong \\ Beijing Institute of Technology Zhuhai Campus, Zhuhai, China \\ Email address: \\ taro_930@126.com (Lin Huijuan), qianhong_0504@qq.com (Huang Qianhong)
}

\section{To cite this article:}

Lin Huijuan, Huang Qianhong. Factors Analysis on the Level of Cash Dividend in Chinese Gem Listed Companies. Journal of Finance and Accounting. Vol. 4, No. 4, 2016, pp. 239-244. doi: 10.11648/j.jfa.20160404.20

Received: June 27, 2016; Accepted: August 1, 2016; Published: August 3, 2016

\begin{abstract}
The growth enterprise market (gem), which has the characteristic of strong cash dividend, is a supplement to the main board market and take an indispensable part in the financing platform and the multi-level capital market in China, but the current achievements in the research reveals that researchers who studied the cash dividend mostly based on the main board market rather than gem, however, the characteristics of the gem companies and their cash dividends are different from the main board market due to the particularities of their own. Therefore, basing on the current achievements in the research, the characteristics of cash dividend in gem companies and the main factors that influence the paying level of the cash dividend are analyzed in this paper.
\end{abstract}

Keywords: Growth Enterprise Market (Gem), Cash Dividends, Affecting Factors

\section{Introduction}

Since the first batch of companies listed on the gem in October 2009, gem company's size, quantity, etc, all show the state of rapid development, so far, the company number has more than four hundred and the total value reach up to four trillion Chinese yuan, it can be seen that the gem, which is an important component of the multi-level capital market in China, creates an entrepreneurship environment for the masses and produces the power that support small and medium-sized companies. In addition, dividend distribution, especially the cash dividend distribution, as the main part of financial management, is an important method for managers to operate the company' funds and balance the interests of all parties, so the dividend problem has always been the research focus of scholars both at China and abroad. However, due to the development of the gem is not perfect, and most of the focus is on the main board market, gem researches that closely related to the securities market and people's vital interests are rare. Therefore, basing on the current achievements in the research, the main factors that influence the paying level of the cash dividend are going to be analyzed in this paper, expecting to provide ideas for managers to formulate the dividend policy and for investors to judge the company's operating conditions.

\section{Current Research Status of Cash Dividend in the Gem Companies}

Western gem, which began in the middle of the 20th century, is perfectly developed. Its basic theories are mature and researches were profound. However, the establishment of the gem in China is less than seven years, the development is still not perfect, scholars analyzed the gem companies mostly based on western theories and models, the researches were not good and still need further study.

\subsection{Factors Analysis of Cash Dividend}

According to the current researches, due to the variety of research time, research methods and market conditions, the influencing factors of cash dividend have certain differences, but always include eight factors: company size, profitability, solvency, equity concentration, operating cash flow, monetary capital adequacy, growth ability and surplus income.

Scholars generally agree that profitability, solvency, equity concentration, operating cash flow, monetary capital adequacy and surplus income level is positively correlated with the company's cash dividend. Among them, two 
academics argued that the more profits of the company, the more likely adopt high cash dividend policy [1]. An expert believed that dividend policy is one of the most important research topics of modern corporate finance, asset-liability ratio must be taken into account in mapping out the dividend policy and the heavier liability of the company, the less likely dispatch high cash dividend [2]. What's more, two experts (2009) considered that surplus income is positively correlated with company's cash dividend rate [3]. About gem companies in China, a scholar thought that with the rapid development of the gem, the company gets more and more profits, and he argued that the current dividend policy is positively influenced by profitability. Besides, he also argued that the more concentrated the company's equity, the less cash dividend, since the big shareholders can't obtain huge return through share price difference in the short term. They always expect a huge number of cash dividends, so as to improve the company's reputation and share price and obtain high capital gains in the future [4]. Another scholar believed that the higher solvency risk, the weaker sustainable operation ability of company, so company which is under the high solvency is unwilling to dispatch its surplus income [5]. Two specialists found that gem company distributes cash dividend mainly depends on its cash flow, which is the same as general listed company [6].

On the relationship between cash dividend and company size, different scholars have different opinions. An Chinese scholar concluded that the larger the company, the more cash dividend [7]. On the contrary, basing on Chinese first batch of 28 listed companies, another Chinese scholar explained that the average shares of gem companies in 2009 are 113.77 million while the cash dividend reached up to 0.24 yuan per share [8].

And on the relationship between cash dividend and growth ability, most of the scholars believe that the two are positively correlated, but there are also a few scholars have opposite views. An Chinese expert claimed that gem company, which growth ability is strong, tends to accumulate its profits for its own investment and development [9]. Besides, another expert argued that most of the gem companies are small and medium-sized enterprises, they want to spend a lot of money on their own development rather than distributing cash dividend even if their growth ability is strong [10].

\subsection{Research Methods on Cash Dividend}

Scholars always study cash dividend of gem companies through the empirical analysis method. Among them, most of the scholars established multiple regression model by regression analysis method. However, some scholars adopted factor analysis method, descriptive statistical analysis method, etc.

\section{State of Cash Dividend in Chinese Gem Companies}

According to the dividend policy of Chinese gem companies from 2009 to 2014, current state of cash dividend in gem companies is as follow:
(1) Lots of companies tend to distribute cash dividend.

Table 1. Undistributed and distributed proportion of gem companies.

\begin{tabular}{lll}
\hline & Undistributed & Distributed \\
\hline 2009 & $29 \%$ & $71 \%$ \\
2010 & $28 \%$ & $72 \%$ \\
2011 & $14 \%$ & $86 \%$ \\
2012 & $13 \%$ & $87 \%$ \\
2013 & $12 \%$ & $88 \%$ \\
2014 & $18 \%$ & $82 \%$ \\
\hline
\end{tabular}

Table 1 shows that, from 2009 to 2014, a number of companies distributed cash dividend, and from 2009 to 2013, the proportion was steadily rising, especially in 2013, it reached up to $88 \%$. In 2014 , it had fallen, but the proportion was still very high.

(2) Strong Cash dividend.

Table 2. State of cash dividend. Unit: Chinese yuan/share.

\begin{tabular}{lllll}
\hline & Min & Max & Average & Standard Deviation \\
\hline 2009 & 0.1 & 0.65 & 0.268 & 0.1353 \\
2010 & 0.05 & 1.5 & 0.29576 & 0.223911 \\
2011 & 0.02 & 4.5 & 0.24162 & 0.311949 \\
2012 & 0.01 & 0.8 & 0.16607 & 0.142945 \\
2013 & 0.005 & 1 & 0.133795 & 0.136169 \\
2014 & 0.005 & 1.5 & 0.1227317 & 0.145711799 \\
\hline
\end{tabular}

According to table 2, in the early years of Chinese gem, lots of companies adopted strong cash dividend policy and the gap was not large, especially in 2010 , the average reached up to 0.29576 Chinese yuan per share and the standard deviation is 0.223911 . From 2012 to 2014, the strength of distribution was slightly weakened, but the difference between the standard deviation was not obvious, it means that plenty of companies weakened the distribution of cash dividend, but was still in the high level.

\section{Empirical Analysis}

\subsection{Research Hypothesis}

Based on current research findings and combined with the characteristics of Chinese gem companies, eight hypotheses are put forward as follows:

Hypothesis 1: The company scale is positively correlated with cash dividend level.

Hypothesis 2: Profitability is positively correlated with cash dividend level.

Hypothesis 3: Solvency is positively correlated with cash dividend level.

Hypothesis 4: Operating cash flow is positively correlated with cash dividend level.

Hypothesis 5: Equity concentration is positively correlated with cash dividend level.

Hypothesis 6: Monetary capital adequacy is positively correlated with cash dividend level.

Hypothesis 7: Growth ability is negatively correlated with cash dividend level.

Hypothesis 8: Surplus income is positively correlated with cash dividend level. 


\subsection{Evaluation Indices}

Based on current research findings, the evaluation indices are put forward as follows:

(1) The higher the natural log of total asset, the larger the company scale.

(2) The higher the earnings per share, the stronger the profitability.

(3) The lower the asset-liability ratio, the stronger the solvency.

(4) The more operating cash flows per share, the more company operating cash flow.

(5) The higher the share proportion of the largest shareholder, the more concentrated the company's equity.

(6) The higher the proportion of the monetary funds, the more monetary fund.

(7) The higher growth rate of business revenue, the stronger the company growth ability.

(8) The higher the undistributed profit per share, the higher the company's retained earnings.

\subsection{Variable Design}

\subsubsection{Dependent Variable}

Table 3. Dependent variable.

\begin{tabular}{lll}
\hline Dependent variable & Symbol & Formula \\
\hline Cash dividend per share & $\mathrm{Y}$ & $\begin{array}{l}\text { Total amount of cash } \\
\text { dividend/common stock shares }\end{array}$ \\
\hline
\end{tabular}

\subsubsection{Independent Variables}

Table 4. Independent variables

\begin{tabular}{|c|c|c|c|}
\hline $\begin{array}{l}\text { Affecting } \\
\text { factor }\end{array}$ & Symbol & $\begin{array}{l}\text { Independent } \\
\text { Variables }\end{array}$ & Formula \\
\hline Company Size & $\mathrm{X}_{1}$ & $\begin{array}{l}\text { the Natural Log } \\
\text { of Total Asset }\end{array}$ & $\begin{array}{l}\text { the Natural Log of Total } \\
\text { Asset at the End of the } \\
\text { Year }\end{array}$ \\
\hline Profitability & $\mathrm{X}_{2}$ & $\begin{array}{l}\text { Earnings per } \\
\text { Share }\end{array}$ & $\begin{array}{l}\text { After-tax } \\
\text { Profits/Common Stock } \\
\text { Shares }\end{array}$ \\
\hline Solvency & $\mathrm{X}_{3}$ & $\begin{array}{l}\text { Asset-liability } \\
\text { Ratio }\end{array}$ & Debt/Assets \\
\hline $\begin{array}{l}\text { Operating } \\
\text { Cash Flow }\end{array}$ & $\mathrm{X}_{4}$ & $\begin{array}{l}\text { Operating Cash } \\
\text { Flows per Share }\end{array}$ & $\begin{array}{l}\text { Operating Cash } \\
\text { Flows/Common Stock } \\
\text { Shares }\end{array}$ \\
\hline $\begin{array}{l}\text { Equity } \\
\text { Concentration }\end{array}$ & $\mathrm{X}_{5}$ & $\begin{array}{l}\text { Share Proportion } \\
\text { of the Largest } \\
\text { Shareholder }\end{array}$ & $\begin{array}{l}\text { Shares of the Largest } \\
\text { Shareholder /Common } \\
\text { Stock Shares }\end{array}$ \\
\hline $\begin{array}{l}\text { Monetary } \\
\text { Capital } \\
\text { Adequacy }\end{array}$ & $\mathrm{X}_{6}$ & $\begin{array}{l}\text { Proportion of the } \\
\text { Monetary Funds }\end{array}$ & Monetary Fund/Assets \\
\hline $\begin{array}{l}\text { Growth } \\
\text { Ability }\end{array}$ & $\mathrm{X}_{7}$ & $\begin{array}{l}\text { Growth Rate of } \\
\text { Business Revenue }\end{array}$ & $\begin{array}{l}\text { (Total Revenue This } \\
\text { Year-Total Revenue } \\
\text { Last Year)/Total } \\
\text { Revenue Last Year }\end{array}$ \\
\hline $\begin{array}{l}\text { Surplus } \\
\text { Income }\end{array}$ & $\mathrm{X}_{8}$ & $\begin{array}{l}\text { Undistributed } \\
\text { Profit per Share }\end{array}$ & $\begin{array}{l}\text { Undistributed } \\
\text { Profit/Common Stock } \\
\text { Shares }\end{array}$ \\
\hline
\end{tabular}

\subsection{Sample Selection and Data Sources}

From 2009 to 2014 of 1516 companies, 50 companies are chosen by stratified sampling method and the number from 2009 to 2014 is $2,5,9,10,11,13$. Before the research, making the explanation as follows:

(1) All the original data are from Shenzhen Stock Exchange, China and Securities Star, China.

(2) Cash dividend in this paper refers to the common stock cash dividend per year.

(3) Data processing software is SPSS 19.0 and Excel 2010.

\subsection{Normal Distribution Test}

From frequency analysis of SPSS, data obey the normal distribution approximately and don't need the standardization.

\subsection{Establishment of Model}

Basing on the regression analysis method, model is established as follows:

$$
\mathrm{Y}=\mathrm{B}_{0}+\mathrm{B}_{1} \mathrm{X}_{1}+\mathrm{B}_{2} \mathrm{X}_{2}+\mathrm{B}_{3} \mathrm{X}_{3}+\mathrm{B}_{4} \mathrm{X}_{4}+\mathrm{B}_{5} \mathrm{X}_{5}+\mathrm{B}_{6} \mathrm{X}_{6}+\mathrm{B}_{7} \mathrm{X}_{7}+\mathrm{B}_{8} \mathrm{X}_{8}+\varepsilon
$$

$\mathrm{B}_{0}$ is constant, $\mathrm{B}_{1}-\mathrm{B}_{8}$ are the influence degree of the independent variable on the dependent variable, $\varepsilon$ is random error.

\subsection{Regression Analysis}

\subsubsection{Description Analysis}

Table 5. Description.

\begin{tabular}{|c|c|c|c|c|}
\hline & Min & $\operatorname{Max}$ & Average & $\begin{array}{l}\text { Standard } \\
\text { deviation }\end{array}$ \\
\hline \multirow{2}{*}{$\begin{array}{l}\text { Cash Dividend per Share } \\
\text { the Natural Log of Total } \\
\text { Asset }\end{array}$} & 0.02 & 0.5 & 0.17568 & 0.133434 \\
\hline & 18.8628 & 23.0075 & 20.77398 & 0.712839 \\
\hline Earnings per Share & 0.04 & 1.77 & 0.566588 & 0.388323 \\
\hline Asset-liability Ratio & 0.026 & 1.0942 & 0.205284 & 0.185786 \\
\hline $\begin{array}{l}\text { Operating Cash Flows per } \\
\text { Share }\end{array}$ & -1.4102 & 1.4678 & 0.185408 & 0.544524 \\
\hline $\begin{array}{l}\text { Share Proportion of the } \\
\text { Largest Shareholder }\end{array}$ & 0.09 & 0.6148 & 0.315684 & 0.101787 \\
\hline $\begin{array}{l}\text { Proportion of the } \\
\text { Monetary Funds }\end{array}$ & 0.1186 & 2.9925 & 0.490797 & 0.413717 \\
\hline $\begin{array}{l}\text { Growth Rate of Business } \\
\text { Revenue }\end{array}$ & -0.2029 & 0.6758 & 0.219046 & 0.224 \\
\hline $\begin{array}{l}\text { Undistributed Profit per } \\
\text { Share }\end{array}$ & 0.34 & 3.13 & 1.3546 & 0.584599 \\
\hline
\end{tabular}

Table 5 shows that, from the point of cash dividends level, the average of cash dividend per share is 0.17568 , and from the point of the difference of cash dividend level, the standard deviation of the cash dividend per share is 0.133434 , it means that gap is not big, cash dividends are all on high level. What's more, from the perspective of the eight indices, the average and standard deviation of the natural log of total asset are not big, it indicates that most of the company are on a smaller scale; the average of the earnings per share is high while the standard deviation is small, it suggests that the company 
profitability is strong, which contributes to the distribution of cash dividend; the average of asset-liability ratio are not big and the gap of 50 companies is small, suggesting that debt pressure is generally small; the average of operating cash flows per share is low, and the minimum is -1.4103 , which stand in vivid contrast against the high cash dividend, meaning that even if there is no cash income in daily operation, some of the companies also distribute cash dividend; average of share proportion of the largest shareholder is 0.315684 and the standard deviation is 0.101787 , it shows that in most companies, the largest shareholder has a certain controlling strength; proportion of monetary funds is and it explain that most companies have sufficient cash flow; average of revenue growth rate is not high, but the maximum is 0.6758 , indicating a part of the companies' growth ability is excellent; and the average of undistributed profit per share is not low, indicating most of the company accumulate a wealth of distributable profits.

\subsubsection{Correlation Analysis}

Table 6. Correlation.

\begin{tabular}{|c|c|c|c|c|c|c|c|c|}
\hline & $\begin{array}{l}\text { the Natural } \\
\text { Log of Total } \\
\text { Asset }\end{array}$ & $\begin{array}{l}\text { Earnings } \\
\text { per Share }\end{array}$ & $\begin{array}{l}\text { Asset-liability } \\
\text { Ratio }\end{array}$ & $\begin{array}{l}\text { Operating } \\
\text { Cash Flows } \\
\text { per Share } \\
\end{array}$ & $\begin{array}{l}\text { Share Proportion } \\
\text { of the Largest } \\
\text { Shareholder }\end{array}$ & $\begin{array}{l}\text { Proportion of } \\
\text { the Monetary } \\
\text { Funds }\end{array}$ & $\begin{array}{l}\text { Growth Rate } \\
\text { of Business } \\
\text { Revenue } \\
\end{array}$ & $\begin{array}{l}\text { Undistributed } \\
\text { Profit per } \\
\text { Share } \\
\end{array}$ \\
\hline $\begin{array}{l}\text { the Natural Log of } \\
\text { Total Asset }\end{array}$ & 1 & -0.014 & -0.068 & -0.176 & -0.069 & $-0.419^{* *}$ & -0.024 & 0.017 \\
\hline Earnings per Share & -0.014 & 1 & 0.14 & 0.269 & -0.025 & $0.503^{* *}$ & $0.495^{* *}$ & $0.725^{* *}$ \\
\hline $\begin{array}{l}\text { Asset-liability } \\
\text { Ratio }\end{array}$ & -0.068 & 0.14 & 1 & -0.05 & 0.02 & $0.33^{*}$ & $0.33^{*}$ & 0.021 \\
\hline $\begin{array}{l}\text { Operating Cash } \\
\text { Flows per Share }\end{array}$ & -0.176 & 0.269 & -0.05 & 1 & -0.213 & 0.273 & 0.177 & -0.001 \\
\hline $\begin{array}{l}\text { Share Proportion } \\
\text { of the Largest } \\
\text { Shareholder }\end{array}$ & -0.069 & -0.025 & 0.02 & -0.213 & 1 & 0.014 & -0.095 & -0.041 \\
\hline $\begin{array}{l}\text { Proportion of the } \\
\text { Monetary Funds }\end{array}$ & $-0.419^{* *}$ & $0.503^{* *}$ & $0.33^{*}$ & 0.273 & 0.014 & 1 & 0.068 & $0.286^{*}$ \\
\hline $\begin{array}{l}\text { Growth Rate of } \\
\text { Business Revenue }\end{array}$ & -0.024 & $0.495^{* *}$ & $0.33^{*}$ & 0.177 & -0.095 & 0.068 & 1 & 0.21 \\
\hline $\begin{array}{l}\text { Undistributed } \\
\text { Profit per Share }\end{array}$ & 0.017 & $0.725^{* *}$ & 0.021 & -0.001 & -0.041 & $0.286^{*}$ & 0.21 & 1 \\
\hline
\end{tabular}

**means: At the 0.01 level. *means: At the 0.05 level.

Table 6 shows that there are some relationship among the independent variables, the proportion of monetary fund is weakly and positively correlated with undistributed profit per share and the earnings per share, asset-liability ratio is weakly and positively correlated with the proportion of monetary funds, increase rate of business revenue, too. However, the natural log of total asset is weakly and negatively correlated with the proportion of the monetary funds. What's more, the earnings per share and undistributed profit per share has significant positive correlation. Due to the correlation among the independent variables, the multicollinearity diagnosis is going to be done in the next part.

\subsubsection{Multicollinearity Diagnosis}

Table 7. Multicollinearity Diagnosis.

\begin{tabular}{lll}
\hline & Tolerance & VIF \\
\hline the Natural Log of Total Asset & 0.708 & 1.413 \\
Earnings per Share & 0.208 & 4.797 \\
Asset-liability Ratio & 0.693 & 1.444 \\
Operating Cash Flows per Share & 0.742 & 1.348 \\
Share Proportion of the Largest & 0.916 & 1.092 \\
Shareholder & 0.402 & 2.485 \\
Proportion of the Monetary Funds & 0.506 & 1.977 \\
Growth Rate of Business Revenue & 0.384 & 2.607 \\
Undistributed Profit per Share & & \\
\hline
\end{tabular}

From table 7 , independent variables' tolerances are greater than 0.1 , and VIFs are far less than 10. It means that there was no serious multicollinearity problem among the independent variables.

\subsubsection{Regression Analysis}

Because of the correlation among independent variables, the stepwise regression analysis method was adopted to establish the linear regression model.

Table 8. Model summary.

\begin{tabular}{lll}
\hline $\mathbf{R}$ & R Square & Adjusted R Square \\
\hline 0.839 & 0.703 & 0.691 \\
\hline
\end{tabular}

Table 9. Anova.

\begin{tabular}{llllll}
\hline & Sum of Squares & Df & Mean Square & F & Sig. \\
\hline Regression & 0.613 & 2 & 0.307 & 55.665 & 0 \\
Residual & 0.259 & 47 & 0.006 & & \\
Total & 0.872 & 49 & & & \\
\hline
\end{tabular}

Table 10. Coefficients.

\begin{tabular}{llllll}
\hline & $\begin{array}{l}\text { Standardized } \\
\text { Coefficients }\end{array}$ & $\begin{array}{l}\text { Unstandardized } \\
\text { Coefficients }\end{array}$ & t & Sig. \\
\hline (Constant) & 0.08 & & 3.79 & 0 \\
Earnings per Share & 0.273 & 0.795 & 9.908 & 0 \\
Asset-liability Ratio & -0.287 & -0.399 & -4.976 & 0 \\
\hline
\end{tabular}


According to table 10, at the 0.05 level, earnings per share and asset-liability ratio are the most obvious factors: earnings per share is positively correlated with cash dividend per share while asset-liability ratio is positively correlated with cash dividend per share. And putting the coefficient $b_{2}, b_{3}$ and constant $b_{0}$ into model, equation is as follows:

$$
\mathrm{Y}=0.088+0.273 \mathrm{X}_{2}-0.287 \mathrm{X}_{3}+\varepsilon
$$

From table 8 , the adjusted R square is 0.691 , indicating the independent variables explain $69.1 \%$ of the change of the dependent variables, and the model is reasonable. What's more, table 9 shows that $F$ statistics is 55.665 and $P$ value is 0 , model passes the significance test of regression equation. In addition, from tables $10, \mathrm{P}$ values are all 0 , model passes the student test and two independent variables have significant linear relationship with the dependent variable. Therefore, the regression conclusion is reliable and the linear regression model has a statistical significance.

\subsubsection{Interpretation of Result}

Analysis above indicates that earnings per share and asset-liability ratio significantly affect the cash dividend level, details are as follows:

(1) The natural log of total asset and cash dividend per share have no obvious correlation, it doesn't support hypothesis 1 .

(2) Earnings per share is positive correlated with cash dividend per share, it supports hypothesis 2 .

(3) Asset-liability ratio is negative correlated with cash dividend per share, it supports hypothesis 3 .

(4) Operating cash flows per share and cash dividend per share have no obvious correlation, it doesn't support hypothesis 4.

(5) Share proportion of the largest shareholder and cash dividend per share have no obvious correlation, it doesn't support hypothesis 5.

(6) Proportion of monetary fund and cash dividend per share have no obvious correlation, it doesn't support hypothesis 6 .

(7) Growth rate of business revenue and cash dividend per share have no obvious correlation, it doesn't support hypothesis 7 .

(8) Undistributed profit per share and cash dividend per share have no obvious correlation, it doesn't support hypothesis 8 .

\section{Conclusion and Suggestion}

\subsection{Conclusion}

Based on the current achievement in the research, the current state of cash dividend in gem companies shows that most companies prefer distributing cash dividend, especially in 2013 , distribution rate reached up to $88 \%$, and the cash dividends level was high, generally from 0.1 to 0.2 Chinese yuan per share, in 2011, a company's cash dividend was as high as 4.5 Chinese yuan per share. In addition, data from 50 companies shows that profitability and solvency are positively correlated with cash dividend level. Profitability is the basic of cash dividend and company which suffer from high debt may not distribute cash dividend, making financial risk higher and higher. However, company size, operating cash flow, equity concentration, monetary, capital adequacy, growth ability, surplus income have nothing to do with the cash dividend level. It means that in gem company, other shareholders have certain ability to balance the largest shareholders, while this ability is limited [11], and it also can correct the wrong thinking that the larger the company, the more fund, the more concentrated the company's equity, the stronger the company growth ability and the higher the company's undistributed profit, the more cash dividend.

\subsection{Suggestion}

\subsubsection{Improve Profitability}

Results above shows that profitability are positively correlated with cash dividend level and is the basic of cash dividend, enterprise manager should put effort into the improvement of management system, taking the advantages of company' strong innovation ability, and gradually improve the profitability, reduce the management risk.

\subsubsection{Attaches Great Importance to the Company's Cash Flow}

Descriptive analysis shows that, even if there is no cash income in daily operation, some of the companies also distribute cash dividend, which may be associated with the company's super fund raised, a large number of idle fund stay in bank account. However, the neglect of the cash flow may damage the rights and interests of shareholders and affect the company's development.

\subsubsection{Consider All Kind of Factors and Formulate Suitable Cash Dividend Policy}

When formulating cash dividend policy, manager should consider not only the macro-environment, such as the national policy, industry status, but also the company's operating state, development prospects, etc. In addition, cash dividend policy should have continuity and stability, it can't be simply changed for the realization of investment and financing.

\subsection{Analysis Limitation}

Analysis above mainly has the following limitation:

(1) In terms of sample quantity, only 50 samples were selected, the results may be different from the real state. The number of sample will be increased for further analysis in the following days.

(2) In terms of independent variables, only eight independent variables were selected, these factors may not fully reflect the company's operating and financial conditions, and all variables could be quantified, factors can't be quantified were not included in this paper, such as laws and regulations, macro-environment. The independent variables will be increased for further analysis in the following days, especially the factors can't be quantified. 


\section{References}

[1] Talat Afza, Hammad Hassan Mirza. Ownership Structure and Cash Flows As Determinants of Corporate Dividend Policy [J]. International Business Research, 2010, 33.

[2] Muhammad Mahbubur Rahman. Managers' Perception towards Dividends and Dividend Policy [J]. Journal of Financial Risk Management, 2015, 0403.

[3] Anupam Parua, Arindam Gupta. Dividend History and Determinants in Selected Companies: a Study During 1993-94 to 2004-05 [J]. Australasian Accounting Business and Finance Journal, 2009, 34.

[4] Ouyang Xiaoming. Study on the gem listed company dividend policy in China $[\mathrm{J}]$. Friends of the accounting (below the ten-day), 2010, 10, 77-79.

[5] Chen Fang. Gem listed company dividend distribution characteristics and the cause analysis [J]. Journal of accounting monthly, 2013, 24: 105-107.

[6] Wang Lin, Li Suying. Chinese gem listed companies cash dividend factors analysis [J]. Journal of Shijiazhuang Railway University (social science edition), 2011, 04: 28-31.

[7] Ye Zheng. Study on the influence factors in Gem listed companies cash dividend [J]. Journal of accounting, 2015, 05: $3-5$.

[8] Zhou Feng. The first 28 gem listed companies dividend policy research [J]. Friends of the accounting, 2013: 95-100.

[9] Yin Piaoyang. Dividend distribution of gem listed companies in our country [J]. Chinese certified public accountants, 2012, 12: 64-70.

[10] Xie Hua. Research on the gem and main board companies cash dividend policy from the Shenzhen stock exchange by factor analysis method [J]. Journal of Hebei University of science and technology (social science edition), 2013 01: 9 to 17.

[11] Wang Huifang. Study on the gem listed company dividend distribution [J]. Journal of securities market leader, 2011 01: 74-77. 